\title{
Effects of Soil Tillage and Foliar Fertilization on Biomass Yield of Post-Harvest Seeded Sorghum Cultivars
}

\author{
Stipešević B*, Brozović B, Jug D, Jug I, Vukadinović V and Đurđević B \\ Faculty of Agriculture, J J Strossmayer University, Vladimira Preloga 1, 31000 Osijek, \\ Croatia
}

*corresponding author: Bojan Stipesevic, Faculty of Agriculture, J J Strossmayer

\section{Mini Review \\ Volume 3 Issue 2}

Received Date: March 30, 2018

Published Date: April 19, 2018 University, Vladimira Preloga 1, 31000 0sijek, Croatia, Tel: +38531554834; Email: bojans@pfos.hr

\section{Abstract}

Recent climate changes lead toward possibility of using longer period of warmer temperatures after winter crops harvest (such as wheat, barley, oilseed rape, etc.) for establishing post-harvest crop, such is sorghum, which can produce significant biomass, useful both for feed and bioenergy, even in drier summers, with reduced soil tillage preparation. The trial was set up in Poljanci, Croatia, in years 2015 and 2016 as a split-split-plot design with foliar fertilizers and sorghum cultivars treatments, established by two soil tillage treatments (SD-single and MD-multiple disk harrowing) after winter barley harvest in mid-July, and picked before autumn frosts at the end of November. Foliar fertilizers treatments were C) Control (no fertilization), B) Biological (Condi agro) and M) Mineral (EcoTop Folimax) foliar fertilizers. Cultivars used in trial were KSH3723, KSH3724, Lemnos, Leonie, Merlin, Sammos, Santos, Sole, Tarzan and Zerberus. Foliar fertilizer treatments $B$ and $M$ showed trend of higher dried biomass yield 7 and 11\% in comparison with C, respectively. Trend was higher at fresh biomass yield, where B and M scored 12 and 22\% higher than C, respectively. There were no statistical differences between soil tillage treatments. The highest fresh biomass yield was recorded for Leonie (32933 $\left.\mathrm{kg} \mathrm{ha}^{-1}\right)$, followed by Lemnos (27467 $\mathrm{kg} \mathrm{ha}^{-1}$ ) and KSH3724 (26600 $\left.\mathrm{kg} \mathrm{ha}^{-1}\right)$, whereas the lowest yield was recorded for Zerberus (19600 kg ha-1).

Keywords: Sammos; Lemnos; Zerberus

\section{Introduction}

High yields in modern agriculture are achievable due to genetic potential of crops and agro techniques, were fertilization makes up to $50 \%$ of crop yield. Nitrogen is one of the most important nutrients used in agricultural systems and contributes strong to the economical performance, sustainability, and improvement of cropping systems; however nitrogen use efficiency is usually reported to be lower than $50 \%$ and the losses of 


\section{Food Science and Nutrition Technology}

added nitrogen fertilizers can be very significant. One of the potential solutions which may contribute to reducing environmental pollution by excess nitrogen is foliar fertilizers application since the total amount of applied nutrients is significantly lower, with higher utilization ratio. Another way to reduced nitrogen pollution is the using of summer crops as catch crops in the period between cash crops, thus reducing $\mathrm{N}$ leaching. Summer catch crops are usually grown in unfavorable weather conditions (precipitation deficiency), which requires reduce of conventional tillage systems. Therefore, the aim of this study was to determine effects of different soil tillage and foliar side-dressing cropping systems for sorghum cultivars (Sorghum spp.) sown in post-harvest cultivation.

\section{Materials and Methods}

The field experiments were carried out on the Family Agricultural Enterprise (FAE) "Stipešević Ivica" near Poljanci, Croatia, during summers 2015 and 2016. The soil type was the eutric brown soil, with favorable crop production properties. The preceding main crop was winter barley (Hordeum sativum L.). In both years, the agro techniques for preceding crop included soil preparation by conventional soil tillage (based on autumn moldboard ploughing at $25-30 \mathrm{~cm}$ ) and recommended fertilization ( $120 \mathrm{~kg} \mathrm{~N}, 100 \mathrm{~kg} \mathrm{P}$ and $120 \mathrm{~kg} \mathrm{~K}$ per ha). Trial was set up as the split-split-plot design in four repetitions, with two levels of soil tillage, three sub-levels of side-dressing and ten sub-sub-levels of sorghum cultivar, with basic plot size for side-dressing of $2 \mathrm{~m} \times 5$ $\mathrm{m}$. Treatments of soil tillage were as follows: MD) one passage with heavy disk harrow up to $15-20 \mathrm{~cm}$, followed by two passages of light disk harrow and seedbed preparation with rotary cultivator; and SD) single passage by heavy disk harrow up to $15-20 \mathrm{~cm}$, followed by seedbed preparation by rotary cultivator. Pre-seeding fertilization was omitted for post-harvest sown sorghum cultivars. Ten sorghum cultivars were used: KSH3723, KSH3724, Lemnos, Leonie, Merlin, Sammos, Santos, Sole, Tarzan and Zerberus. The seeding was performed with available cereal seeder at the depth of $1-3 \mathrm{~cm}$. Subtreatments of side-dressing were as follows: $\mathrm{C}$ ) no-sidedressing control; B) Biological foliar fertilizer (Condi agro), with several aerobic and anaerobic microorganisms, including bacteria, actinomycetes, yeasts and mildews, in rate of $7 \mathrm{l} \mathrm{ha}^{-1}$ in two sprayings; and M) Mineral foliar fertilizer (EcoTop Folimax) which contains both macro (N, P, K, Ca) and micro (B, Cu, Fe, Mn, Mo and $\mathrm{Zn)}$ nutrients, in rate of $5 \mathrm{l} \mathrm{ha}^{-1}$ in two sprayings. Sidedressings were performed 4 and 6 weeks after the seeding in each year. Harvests were performed manually in the last week of October. The Fisher protected LSD means comparisons were performed for $\mathrm{P}=0.05$ significance levels for year, soil tillage, side-dressing and their interactions.

\section{Results and Discussion}

The summer 2015 was hot, with unequal and unusual precipitation pattern; July was very dry, August and September had normal precipitation level, whereas October was extremely wet. On the other hand, the summer 2016 was slightly less hot, with very wet July, dry August, normal September and October. Both had about $300 \mathrm{~mm}$ of precipitations, which was sufficient for all sorghum cultivars. Measured soil tillage resistance showed soil compaction layer on 30-35 cm depth, which is direct consequence of ploughing for many years. Applied soil tillages didn't cause noticeable sub-tillage compaction. Since there was no statistical difference between soil tillage treatments, data was not shown separately (Table 1). Both foliar fertilizers treatments resulted with higher yield in comparison with control. The highest yield was recorded by cultivar Leonie, followed by Lemnos and KSH3724, whereas the lowest yield was recorded by Sammos.

\begin{tabular}{|c|c|c|c|c|c|}
\hline Cultivar & C & B & M & $\begin{array}{c}\text { Cultivar } \\
\text { mean }\end{array}$ & Rank \\
\hline KSH 3723 & 4894 & 5679 & 6602 & $5956 \mathrm{cde}$ & 7 \\
\hline KSH 3724 & 6534 & 6496 & 6436 & $6440 \mathrm{bc}$ & 3 \\
\hline Lemnos & 6636 & 6680 & 7408 & $6878 \mathrm{~b}$ & 2 \\
\hline Leonie & 6844 & 7367 & 8254 & $7579 \mathrm{a}$ & 1 \\
\hline Merlin & 5179 & 6018 & 5872 & $5697 \mathrm{def}$ & 8 \\
\hline Sammos & 4668 & 5008 & 4936 & $4871 \mathrm{~g}$ & 10 \\
\hline Santos & 5499 & 6789 & 4861 & $6164 \mathrm{~cd}$ & 4 \\
\hline Sole & 5300 & 6153 & 6445 & $5975 \mathrm{cde}$ & 6 \\
\hline Tarzan & 5588 & 5323 & 7405 & $6105 \mathrm{~cd}$ & 5 \\
\hline Zerberus & 5691 & 5288 & 4997 & $5262 \mathrm{fg}$ & 9 \\
\hline $\begin{array}{c}\text { Foliars trt. } \\
\text { mean }\end{array}$ & $5683 \mathrm{a}$ & $6080 \mathrm{~b}$ & $6322 \mathrm{~b}$ & 6093 & \\
\hline
\end{tabular}

tmeans labeled with the same lowercase letter for same Cultivar or Foliar side-dressing average in each Year or Means group are not statistically different at $\mathrm{P}>0.05$ significance level.

Table 1: Average dry biomass yield $\left(\mathrm{kg} \mathrm{ha}^{-1}\right)$ of sorghum cultivars and applied foliar treatments, Poljanci site, years 2015 and 201 


\section{Food Science and Nutrition Technology}

\section{Conclusion}

The present study of the effects of soil tillage and sidedressing systems on post-harvest sown sorghum cultivars in Northeastern Croatia suggests better effects with foliar fertilizers in comparison with control, regardless of used soil tillage preparation. The results indicate several cultivars (Leonie, Lemnos and KSH3724) which can be used as successful summer catch crops after winter barley. 